\title{
GROUND-WATER DATA FOR SAN NICOLAS ISLAND,
}

\section{CALIFORNIA, 1989-90}

By Lowell F.W. Duell, Jr., and Charles A. Kaehler

U.S. GEOLOGICAL SURVEY

Open-File Report 91-197

Prepared in cooperation with the

U.S. DEPARTMENT OF THE NAVY

o
n்
மூ 
U.S. DEPARTMENT OF THE INTERIOR

MANUEL LUJAN, JR., Secretary

U.S. GEOLOGICAL SURVEY

Dallas L. Peck, Director

Any use of trade, product, or firm names in this publication is for descriptive purposes only and does not imply endorsement by the U.S. Government.

For sale by the Books and Open-File Reports Section, U.S. Geological Survey

Federal Center, Box 25425

Denver, CO 80225

For additional information write to:

District Chief

U.S. Geological Survey

Federal Building, Room W-2234

2800 Cottage Way

Sacramento, CA 95825 


\title{
CONTENTS
}

\author{
Abstract 1 \\ Introduction 1 \\ Well-numbering system 2 \\ Data for selected wells 2 \\ Well construction 2 \\ Water levels 3 \\ Test for well production 3 \\ Water quality 3 \\ Selected references 4
}

\section{ILLUSTRATIONS}

Figure 1. Map showing location of selected wells on San Nicolas Island 7

2-7. Graphs showing:

2. Lithologic log of well $10 \mathrm{~S} / 26 \mathrm{~W}-25 \mathrm{P} 18$

3. Geophysical, caliper, and lithologic logs of well 10S/26W-34G1 9

4. Geophysical and lithologic logs of well $10 \mathrm{~S} / 26 \mathrm{~W}-34 \mathrm{~L} 1 \quad 10$

5. Geophysical, caliper, and lithologic logs of well 10S/26W-35H1 11

6. Geophysical, caliper, and lithologic logs of well 10S/26W-35P1 12

7. Geophysical and lithologic logs of well 10S/26W-36D1 13

8-11. Graphs showing geophysical, caliper, and lithologic logs of well:

8. $10 \mathrm{~S} / 26 \mathrm{~W}-36 \mathrm{E} 114$

9. $10 \mathrm{~S} / 26 \mathrm{~W}-36 \mathrm{~K} 1 \quad 15$

10. $10 \mathrm{~S} / 26 \mathrm{~W}-36 \mathrm{~L} 116$

11. $10 \mathrm{~S} / 26 \mathrm{~W}-36 \mathrm{M} 117$

12. Graphs showing volume of water pumped and water-level drawdown during testing at selected wells, April and May 199018

\section{TABLES}

Table 1. Records for selected wells 5

2. Chemical analysis of water from selected wells 6 
Multiply
By

To obtain

\begin{tabular}{rcl} 
acre & 0.4047 & hectare \\
acre & 4,047 & square meter \\
foot (ft) & 0.3048 & meter \\
gallon (gal) & 3.785 & liter \\
gallon per day (gal/d) & 0.003785 & cubic meter per day \\
inch (in.) & 25.4 & millimeter \\
mile (mi) & 1.609 & kilometer \\
square mile (mi2) & 259.0 & hectare \\
square mile $\left(\mathrm{mi}^{2}\right)$ & 2.590 & square kilometer \\
\hline
\end{tabular}

Temperature is given in degrees Celsius $\left({ }^{\circ} \mathrm{C}\right)$, which can be converted to degrees Fahrenheit $\left({ }^{\circ} \mathrm{F}\right)$ by the following equation:

$$
\text { Temp. }{ }^{\circ} \mathrm{F}=1.8\left(\text { temp. }{ }^{\circ} \mathrm{C}\right)+32
$$

Sea Level: In this report, "sea level" refers to the National Geodetic Vertical Datum of 1929 (NGVD of 1929)--a geodetic datum derived from a general adjustment of the firstorder level nets of both the United States and Canada, formerly called Sea Level Datum of 1929.

Abbreviations:

min (minutes)

min/d (minutes per day) min/cycle (minutes per cycle)

cycles/d (cycles per day) 


\title{
GROUND-WATER DATA FOR SAN NICOLAS ISLAND, CALIFORNIA, 1989-90
}

\author{
By Lowell F.W. Duell, Jr., and Charles A. Kaehler
}

\begin{abstract}
In an effort to gain geohydrologic knowledge and to increase the availability of ground water to the U.S. Navy on San Nicolas Island, nine test wells were drilled by the U.S. Geological Survey in 1989 and one production well was drilled by the U.S. Navy in 1990 . One of the nine test wells was dry, five produced less than 10 gallons of water per day, two produced between 20 and 30 gallons per day, and one produced 400 gallons per day. The production well produced about 900 gallons per day.
\end{abstract}

Water samples were collected from eight wells during 1989-90 and analyzed for concentrations of major dissolved inorganic ions and nutrients. Five of the sampled wells were constructed in 1989, one was constructed in 1990, and two were constructed prior to 1989.

Data from the study are presented in tables and graphs. Included are geophysical, lithologic, and wellconstruction data and results obtained from well-pumping tests and from the chemical analysis of water from selected wells.

\section{INTRODUCTION}

Water for domestic use on San Nicolas Island (fig. 1), a U.S. Naval base, historically has been obtained from local sources--wells, springs, surface-water diversion, and a seawater distillation plant--and from the mainland (transported by barge). During 1990 some existing wells were not pumped because of declining water levels, poor water quality, and casing-corrosion problems. Prior to 1990, spring discharges had decreased and the distillation plants had been discontinued. To gain geohydrologic knowledge and to increase the availability of ground water on San Nicolas Island, the U.S. Geological Survey, in cooperation with the U.S. Department of the Navy, drilled and constructed nine test wells on the island in 1989 and the U.S. Navy drilled one production well in 1990. The wells were developed and test pumped, and six were sampled for chemical analysis. Two wells constructed prior to 1989 also were sampled for chemical analysis. The purpose of this report it to present results obtained from the well-pumping tests and from the chemical analyses, along with geophysical, lithologic, and well-construction data.

San Nicolas Island, which is occupied solely by U.S. Naval installations, is in the Pacific Ocean about $90 \mathrm{mi}$ southwest of Los Angeles, California (fig. 1). The roughly oval-shaped island is about $9 \mathrm{mi}$ long and $3 \mathrm{mi}$ wide at its greatest extent, and its area is approximately 23 $\mathrm{mi}^{2}$. The highest altitude on the island is $907 \mathrm{ft}$ above sea level. 


\section{WELL-NUMBERING SYSTEM}

Wells are numbered according to their location in the rectangular system for subdivision of public land. For example, in well number $10 \mathrm{~S} / 26 \mathrm{~W}-25 \mathrm{P} 1$, that part of the number preceding the slash indicates the township ( $T$. $10 \mathrm{~S}$.); the number and letter following the slash indicate the range (R. 26 W.); the number following the hyphen indicates the section (sec. 25 ); and the letter (P) indicates the 40-acre subdivision of the section according to the lettered diagram below. The final digit (1) is a serial number for wells in each 40 -acre subdivision. The area covered by this report lies in the southwest quadrant of the San Bernardino base line and meridian. In figure 1 , township and range designations are given along the margin of the map. The diagram below shows how well number $10 \mathrm{~S} / 26 \mathrm{~W}-25 \mathrm{P} 1$ is derived.

\section{DATA FOR SELECTED WELLS}

\section{WELL CONSTRUCTION}

The 10 wells drilled during $1989-90$ by the U.S. Geological Survey and the U.S. Navy were located in the areas thought most likely to produce potable ground water. The 10 -inchdiameter holes were drilled by the direct mudrotary method to depths ranging from 62 to 142 $\mathrm{ft}$ below land surface. Geophysical, caliper, and lithologic logs for wells drilled during 1989-90 are shown in figures 2-11.

The wells were cased with 6-inch-diameter PVC (polyvinyl chloride) casing. For the perforated intervals, either continuous-slot screen or slotted casings were used. The slot size is 0.03 in. The annular space in the wells drilled by the U.S. Geological Survey was filled with

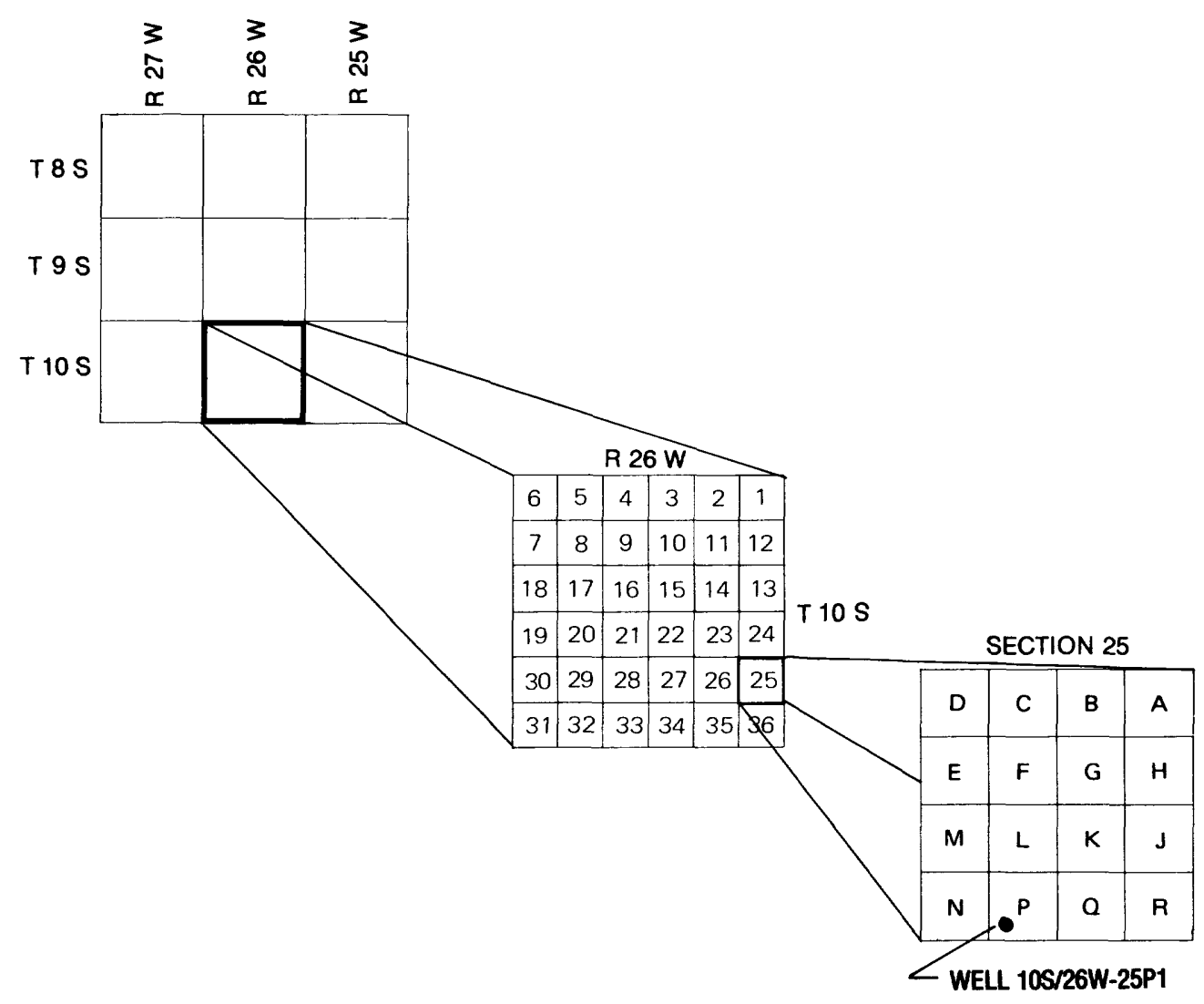


Monterey sand (well-sorted medium sand) from the bottom of the annular space to the top of the perforated interval. The remainder of the annular space was filled with cement to land surface. The annular space in the well drilled by the U.S. Navy was filled with pea gravel from the bottom to $10 \mathrm{ft}$ below land surface, and with cement to land surface. Complete wellconstruction data are given in table 1 .

\section{WATER LEVELS}

Water levels were measured periodically with a steel tape in all the wells drilled during 1989-90 and in some older wells. The location of the wells is shown in figure 1 , and the water levels are given in table 1 .

\section{TEST FOR WELL PRODUCTION}

Wells drilled in 1989-90 were tested with a submersible pump to estimate well production. Test data are shown in figure 12 and include the volume of water pumped, pumping time (indicated in graphs by the width of the bars), and water-level drawdown. A pressure transducer and a data logger were used to monitor water levels during the pumping and recovery phase of the tests in wells $10 \mathrm{~S} / 26 \mathrm{~W}-25 \mathrm{P} 1$, 10S/26W-36D1, 10S/26W-36E1, and 10S/26W$36 \mathrm{~K} 1$. The transducer and data logger allow measurement and recording of water levels as frequently as once per second. Water levels were measured intermittently with an electric sounder in wells $10 \mathrm{~S} / 26 \mathrm{~W}-34 \mathrm{G} 1,10 \mathrm{~S} / 26 \mathrm{~W}$ $34 \mathrm{~L} 1,10 \mathrm{~S} / 26 \mathrm{~W}-36 \mathrm{~L} 1$, and 10S/26W-36M1. Static water levels were not obtained for wells 10S/26W-25P1 and 10S/26W-36L1 because the pumping tests began shortly after well development. Pumping data are not given for well
10S/26W-35P1 because it was dry and for well $10 \mathrm{~S} / 26 \mathrm{~W}-35 \mathrm{H} 1$ because the water level in the well did not recover within 9 days after 9 gal (the entire casing volume) of water was removed.

The amount of drawdown, volume of water pumped per cycle, and rate of water-level recovery obtained from the short-term tests can be used to estimate yield for each well. For example, at well 10S/26W-25P1 (fig. 12), an average of 95 gal of water was pumped during four consecutive 150-min pumping and recovery cycles (based on time needed for full or nearly full recovery) during a representative part of the test. A well-yield estimate of about 900 $\mathrm{gal} / \mathrm{d}$ is obtained by multiplying $95 \mathrm{gal} / \mathrm{cycle}$ times 9.6 cycles/d $(1,440 \mathrm{~min} / \mathrm{d} \div 150 \mathrm{~min} /$ cycle $=9.6$ cycles $/ \mathrm{d}$ ). Yield estimates for each well are given in table 1.

\section{WATER QUALITY}

Water samples were collected from eight wells using standard U.S. Geological Survey field techniques (U.S. Geological Survey, 1977). Water samples were analyzed for major dissolved inorganic ions and nutrients (nitrogen and phosphorus) by the U.S. Geological Survey laboratory in Arvada, Colorado. The methods used for laboratory analyses are those described by Fishman and Friedman (1989). The analyses are given in table 2 .

Five of the sampled wells were drilled by the U.S. Geological Survey in 1989, one was drilled by the U.S. Navy in 1990, and two were older wells. The other four wells drilled by the U.S. Geological Survey were not sampled because of very low production rates and the inability to fully develop the wells to obtain samples uncontaminated by drilling fluids. 


\section{SELECTED REFERENCES}

Brockmeir Consulting Engineers, Inc., 1986, Study of water system for San Nicolas Island--phase 2 (pre-final submittal): Santa Monica, California, 87 p. and 4 appendixes [available for inspection at U.S. Geological Survey, 5735 Kearny Villa Road, Suite O, San Diego, CA 92123].

Burnham, W.L., Kunkel, Fred, Hofmann, Walter, and Peterson, W.C., 1963, Hydrogeologic reconnaissance of San Nicolas Island, California: U.S. Geological Survey Water-Supply Paper 1539-O, 43 p.
Fishman, M.J., and Friedman, L.C., eds, 1989, Methods for determination of organic substances in water and fluvial sediments: U.S. Geological Survey Techniques of Water-Resources Investigations, Book 5, Chapter A1, 545 p.

U.S. Geological Survey, 1977, National handbook of recommended methods for water-data acquisition: U.S. Geological Survey (Office of Water Data Coordination), Reston, Virginia, Chapter 2 (issued January 1980), 149 p., and Chapter 5 (issued March 1982), $194 \mathrm{p}$. 
Table 1. Records for selected wells

[All wells are in T. 10 S., R. 26 W. Water level: R, well had been recently pumped (within 24 hours prior to measurement). --, no data available; $<$, actual value less than value shown]

\begin{tabular}{|c|c|c|c|c|c|c|c|c|c|c|}
\hline $\begin{array}{l}\text { State well } \\
\text { number }\end{array}$ & $\begin{array}{l}\text { Local } \\
\text { identifi- } \\
\text { cation }\end{array}$ & $\begin{array}{l}\text { Date of } \\
\text { well } \\
\text { construc- } \\
\text { tion }\end{array}$ & $\begin{array}{c}\text { Altitude } \\
\text { of land } \\
\text { surface, } \\
\text { in feet } \\
\text { above } \\
\text { sea level }\end{array}$ & $\begin{array}{c}\text { Dia- } \\
\text { meter } \\
\text { of } \\
\text { casing, } \\
\text { in } \\
\text { inches }\end{array}$ & $\begin{array}{l}\text { Depth of } \\
\text { well, in } \\
\text { feet } \\
\text { below } \\
\text { land } \\
\text { surface }\end{array}$ & $\begin{array}{c}\text { Perfora- } \\
\text { tion } \\
\text { interval, } \\
\text { in feet } \\
\text { below } \\
\text { land } \\
\text { surface }\end{array}$ & $\begin{array}{c}\text { Measure } \\
\text { point } \\
\text { (top of } \\
\text { casing), } \\
\text { in feet } \\
\text { above } \\
\text { land } \\
\text { surface }\end{array}$ & $\begin{array}{c}\text { Date of } \\
\text { water- } \\
\text { level mea- } \\
\text { surement }\end{array}$ & $\begin{array}{l}\text { Water } \\
\text { level, } \\
\text { in feet } \\
\text { below } \\
\text { land } \\
\text { surface }\end{array}$ & $\begin{array}{c}\text { Esti- } \\
\text { mated } \\
\text { well } \\
\text { yield, in } \\
\text { gallons } \\
\text { per day }\end{array}$ \\
\hline $25 \mathrm{P} 1$ & $\begin{array}{l}\text { Humphrey } \\
\text { sump \#1 }\end{array}$ & $04-30-90$ & 420 & 6 & 100 & $10-40$ & 2.0 & $05-02-90$ & R7.55 & 900 \\
\hline $34 \mathrm{C} 1$ & $\begin{array}{c}\text { Test well } \\
\quad \# 5\end{array}$ & $\begin{array}{r}\text { October } \\
1960\end{array}$ & 90 & 8 & 47 & - & 2.1 & $\begin{array}{l}08-11-89 \\
05-04-90 \\
06-19-90\end{array}$ & $\begin{array}{l}25.53 \\
25.60 \\
25.70\end{array}$ & - \\
\hline $34 \mathrm{G} 1$ & A-7 & $08-10-89$ & 250 & 6 & 142 & $\begin{array}{c}45-52 \\
80.5-132\end{array}$ & 2.6 & $\begin{array}{l}09-15-89 \\
04-23-90 \\
05-02-90 \\
06-19-90\end{array}$ & $\begin{array}{l}118.55 \\
120.34 \\
120.00 \\
119.22\end{array}$ & $<10$ \\
\hline $34 \mathrm{~L} 1$ & B-8 & $08-14-89$ & 120 & 6 & 65 & $34-60$ & 2.7 & $\begin{array}{l}09-15-89 \\
03-07-90 \\
04-23-90 \\
06-19-90\end{array}$ & $\begin{array}{l}48.26 \\
44.98 \\
45.12 \\
45.27\end{array}$ & $<10$ \\
\hline $35 \mathrm{H} 1$ & D-2 & $08-06-89$ & 590 & 6 & 62 & $23-53$ & 2.8 & $\begin{array}{l}09-15-89 \\
03-05-90 \\
04-23-90 \\
06-19-90\end{array}$ & $\begin{array}{l}53.91 \\
50.94 \\
50.90 \\
55.10\end{array}$ & $<10$ \\
\hline $35 \mathrm{P} 1$ & C-1 & $08-04-89$ & 705 & 6 & 78 & $36-68$ & 1.6 & $\begin{array}{l}08-06-89 \\
03-05-90 \\
04-23-90 \\
06-19-90\end{array}$ & $\begin{array}{l}\text { Dry } \\
\text { Dry } \\
\text { Dry } \\
\text { Dry }\end{array}$ & - \\
\hline 36D1 & E-5 & 08-08-89 & 543.4 & 6 & 69 & $\begin{array}{l}29-39 \\
44-49\end{array}$ & 2.5 & $\begin{array}{l}09-11-89 \\
03-05-90 \\
04-23-90 \\
06-19-90\end{array}$ & $\begin{array}{l}43.96 \\
49.30 \\
49.41 \\
50.03\end{array}$ & 30 \\
\hline $36 \mathrm{E} 1$ & $\mathbf{H}-3$ & $08-06-89$ & 583 & 6 & 39 & $24-34$ & 1.9 & $\begin{array}{l}09-11-89 \\
03-05-90 \\
04-23-90 \\
06-19-90\end{array}$ & $\begin{array}{l}30.06 \\
30.13 \\
30.26 \\
30.43\end{array}$ & $<10$ \\
\hline $36 \mathrm{~F} 1$ & $\begin{array}{c}\text { Well \#1 } \\
\text { (Navy C) }\end{array}$ & $\begin{array}{r}1950 \text { or } \\
1951\end{array}$ & 590.7 & - & 67 & - & 0 & $08-07-89$ & R29.68 & - \\
\hline $36 \mathrm{~F} 2$ & $\begin{array}{c}\text { Well \#6 } \\
\text { (Dale's } \\
\text { well) }\end{array}$ & $\begin{array}{r}\text { August } \\
1988\end{array}$ & 586 & 6 & 330 & $\begin{array}{c}50-70 \\
90-110 \\
250-330\end{array}$ & 2.0 & $09-13-89$ & R37.88 & - \\
\hline $36 \mathrm{F3}$ & $\begin{array}{c}\text { Well \#2 } \\
\text { (Navy D) }\end{array}$ & $\begin{array}{r}1950 \text { or } \\
1951\end{array}$ & 571 & 12 & 72 & -- & 0 & $06-19-90$ & R60.00 & - \\
\hline $36 \mathrm{G} 1$ & $\begin{array}{l}\text { Well \#3 } \\
\text { (Navy E) }\end{array}$ & $\begin{array}{r}1950 \text { or } \\
1951\end{array}$ & 572 & 12 & 80 & - & 0 & $08-07-90$ & 47.00 & - \\
\hline $36 \mathrm{~K} 1$ & G-4 & $08-07-89$ & 600.5 & 6 & 64 & $37-59$ & 3.8 & $\begin{array}{l}09-15-89 \\
03-05-90 \\
03-07-90 \\
04-23-90 \\
06-19-90\end{array}$ & $\begin{array}{l}45.25 \\
43.67 \\
43.72 \\
44.01 \\
44.29\end{array}$ & 20 \\
\hline $36 \mathrm{~L} 1$ & $1-9$ & $08-15-89$ & 595 & 6 & 74 & $34-74$ & 1.8 & $\begin{array}{l}09-15-89 \\
03-05-90\end{array}$ & $\begin{array}{r}37.61 \\
\text { R64.24 }\end{array}$ & 400 \\
\hline $36 \mathrm{M} 1$ & F-6 & 08-09-89 & 633 & 6 & 80 & $\begin{array}{l}27-57 \\
70-75\end{array}$ & 2.7 & $\begin{array}{l}09-15-89 \\
03-05-90 \\
03-06-90 \\
04-23-90 \\
06-19-90\end{array}$ & $\begin{array}{l}56.80 \\
55.12 \\
55.30 \\
55.17 \\
55.20 \\
\end{array}$ & $<10$ \\
\hline
\end{tabular}


Table 2. Chemical analysis of water from selected wells

[All wells are in T. 10 S., R. 26 W. For wells sampled twice, upper value is result for first date and lower value is result for second date. $\mu \mathrm{S} / \mathrm{cm}$, microsiemens per centimeter at $25^{\circ} \mathrm{C} ;{ }^{\circ} \mathrm{C}$, degree Celsius; $\mathrm{mg} / \mathrm{L}$, milligram per liter; $\mu \mathrm{g} / \mathrm{L}$, microgram per liter; --, no data available; <, actual value less than value shown]

\begin{tabular}{|c|c|c|c|c|c|c|c|c|}
\hline State well number. . & . 25P1 & 34G1 & 36D1 & 36E1 & 36F1 & $36 \mathrm{~F} 2$ & $36 \mathrm{~K} 1$ & $36 \mathrm{L1}$ \\
\hline Date & $\begin{array}{l}05-02-90 \\
06-19-90\end{array}$ & $05-02-90$ & $04-29-90$ & $09-15-89$ & $09-15-89$ & $06-19-90$ & $04-30-90$ & $\begin{array}{l}09-15-89 \\
06-19-90\end{array}$ \\
\hline Specific conductance $(\mu \mathrm{S} / \mathrm{cm})$ & $\begin{array}{l}2,330 \\
2,390\end{array}$ & 1,420 & 1,500 & 1,670 & 1,010 & 1,520 & 1,990 & $\begin{array}{l}1,530 \\
1,620\end{array}$ \\
\hline pH (standard units) & $\begin{array}{l}7.30 \\
7.40\end{array}$ & 8.20 & 7.60 & 8.00 & 7.70 & 7.60 & 7.60 & $\begin{array}{l}7.60 \\
7.60\end{array}$ \\
\hline Temperature, water $\left({ }^{\circ} \mathrm{C}\right)$ & $\begin{array}{l}18.0 \\
18.0\end{array}$ & 18.0 & 16.0 & 19.0 & 19.0 & 19.0 & 18.0 & $\begin{array}{l}19.0 \\
18.5\end{array}$ \\
\hline Calcium, dissolved (mg/L as Ca) & $\begin{array}{l}83 \\
78\end{array}$ & 26 & 51 & 50 & 40 & 46 & 46 & $\begin{array}{l}40 \\
40\end{array}$ \\
\hline $\begin{array}{l}\text { Magnesium, dissolved (mg/L } \\
\text { as } \mathrm{Mg} \text { ) }\end{array}$ & $\begin{array}{l}38 \\
35\end{array}$ & 11 & 19 & 19 & 15 & 19 & 18 & $\begin{array}{l}17 \\
17\end{array}$ \\
\hline Sodium, dissolved (mg/L as $\mathrm{Na}$ ) & $\begin{array}{l}380 \\
400\end{array}$ & 240 & 230 & 280 & 150 & 250 & 360 & $\begin{array}{l}280 \\
270\end{array}$ \\
\hline $\begin{array}{l}\text { Potassium, dissolved }(\mathrm{mg} / \mathrm{L} \\
\text { as } \mathrm{K})\end{array}$ & $\begin{array}{l}9.6 \\
9.6\end{array}$ & 5.9 & 8.8 & 9.2 & 8.1 & 8.4 & 8.8 & $\begin{array}{l}9.0 \\
8.2\end{array}$ \\
\hline $\begin{array}{l}\text { Alkalinity, total field }(\mathrm{mg} / \mathrm{L} \\
\left.\text { as } \mathrm{CaCO}_{3}\right)\end{array}$ & $\begin{array}{l}417 \\
409\end{array}$ & 279 & 293 & 298 & 249 & 321 & 353 & $\begin{array}{l}414 \\
392\end{array}$ \\
\hline Sulfate, dissolved $\left(\mathrm{mg} / \mathrm{L}\right.$ as $\left.\mathrm{SO}_{4}\right)$ & $\begin{array}{l}150 \\
150\end{array}$ & 100 & 88 & 110 & 48 & 82 & 86 & $\begin{array}{l}71 \\
81\end{array}$ \\
\hline Chloride, dissolved ( $\mathrm{mg} / \mathrm{L}$ as $\mathrm{Cl}$ ) & $\begin{array}{l}450 \\
450\end{array}$ & 200 & 240 & 310 & 140 & 230 & 390 & $\begin{array}{l}230 \\
220\end{array}$ \\
\hline Fluoride, dissolved (mg/L as F) & $\begin{array}{l}0.60 \\
0.60\end{array}$ & 0.40 & 0.70 & 1.1 & 1.0 & 0.80 & 0.50 & $\begin{array}{l}0.50 \\
0.50\end{array}$ \\
\hline Silica, dissolved (mg/L as $\left.\mathrm{SiO}_{2}\right)$ & $\begin{array}{l}20 \\
18\end{array}$ & 16 & 18 & 19 & 17 & 18 & 17 & $\begin{array}{l}17 \\
17\end{array}$ \\
\hline $\begin{array}{l}\text { Solids, residue at } 180^{\circ} \mathrm{C} \text {, } \\
\text { dissolved }(\mathrm{mg} / \mathrm{L})\end{array}$ & $\begin{array}{l}1,370 \\
1,420\end{array}$ & 814 & 856 & 973 & 557 & 908 & 1,130 & $\begin{array}{l}914 \\
934\end{array}$ \\
\hline $\begin{array}{l}\text { Nitrogen, ammonia, dissolved } \\
(\mathrm{mg} / \mathrm{L} \text { as } \mathrm{N})\end{array}$ & $\begin{array}{l}0.13 \\
0.06\end{array}$ & 0.04 & 0.02 & 0.01 & 0.01 & $<0.01$ & 0.02 & $\begin{array}{l}0.01 \\
0.02\end{array}$ \\
\hline $\begin{array}{l}\text { Nitrogen, ammonia }+ \text { organic, } \\
\text { dissolved }(\mathrm{mg} / \mathrm{L} \text { as } \mathrm{N})\end{array}$ & $\begin{array}{l}0.30 \\
0.30\end{array}$ & 0.80 & 0.60 & 0.30 & 0.20 & 0.40 & $<0.20$ & $\begin{array}{l}<0.20 \\
<0.20\end{array}$ \\
\hline $\begin{array}{l}\text { Nitrogen, } \mathrm{NO}_{2}+\mathrm{NO}_{3} \text {, dissolved } \\
(\mathrm{mg} / \mathrm{L} \text { as } \mathrm{N})\end{array}$ & $\begin{array}{l}<0.10 \\
<0.10\end{array}$ & 5.30 & 2.50 & 2.10 & 1.60 & 1.10 & $<0.10$ & $\begin{array}{l}<0.10 \\
<0.10\end{array}$ \\
\hline $\begin{array}{l}\text { Phosphorus, ortho, dissolved } \\
\text { (mg/L as P) }\end{array}$ & $\begin{array}{r}0.04 \\
<0.01\end{array}$ & 0.12 & 0.04 & 0.09 & 0.03 & $<0.01$ & 0.02 & $\overline{0} .01$ \\
\hline $\begin{array}{l}\text { Phosphorus, dissolved }(\mathrm{mg} / \mathrm{L} \\
\text { as } \mathrm{P})\end{array}$ & $\begin{array}{r}0.54 \\
<0.01\end{array}$ & 0.13 & 0.05 & 0.17 & 0.02 & $<0.01$ & 0.02 & $\overline{0.01}$ \\
\hline Boron, dissolved $(\mu \mathrm{g} / \mathrm{L}$ as $\mathrm{B})$ & $\begin{array}{l}800 \\
760\end{array}$ & 510 & 320 & 310 & 230 & 430 & 490 & $\begin{array}{l}490 \\
520\end{array}$ \\
\hline Iron, dissolved $(\mu \mathrm{g} / \mathrm{L}$ as $\mathrm{Fe})$ & $\begin{array}{r}600 \\
20\end{array}$ & 6 & 14 & 8 & 30 & 5 & 30 & $\begin{array}{l}410 \\
120\end{array}$ \\
\hline $\begin{array}{l}\text { Manganese, dissolved }(\mu \mathrm{g} / \mathrm{L} \\
\text { as Mn) }\end{array}$ & $\begin{array}{l}80 \\
20\end{array}$ & 18 & 26 & 19 & 6 & $<1$ & 40 & $\begin{array}{l}60 \\
12 \\
\end{array}$ \\
\hline
\end{tabular}




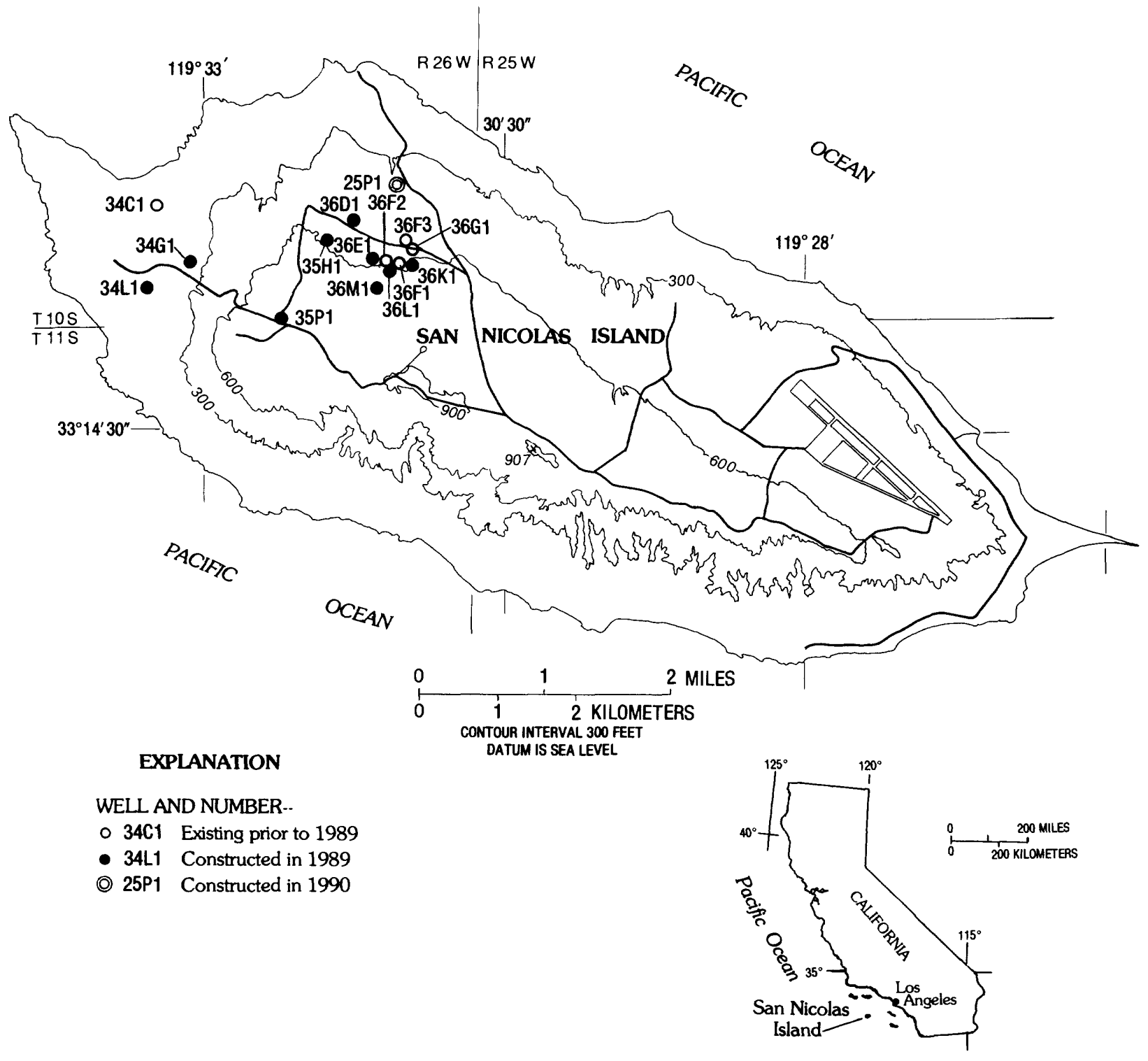

Figure 1. Location of selected wells on San Nicolas Island. 


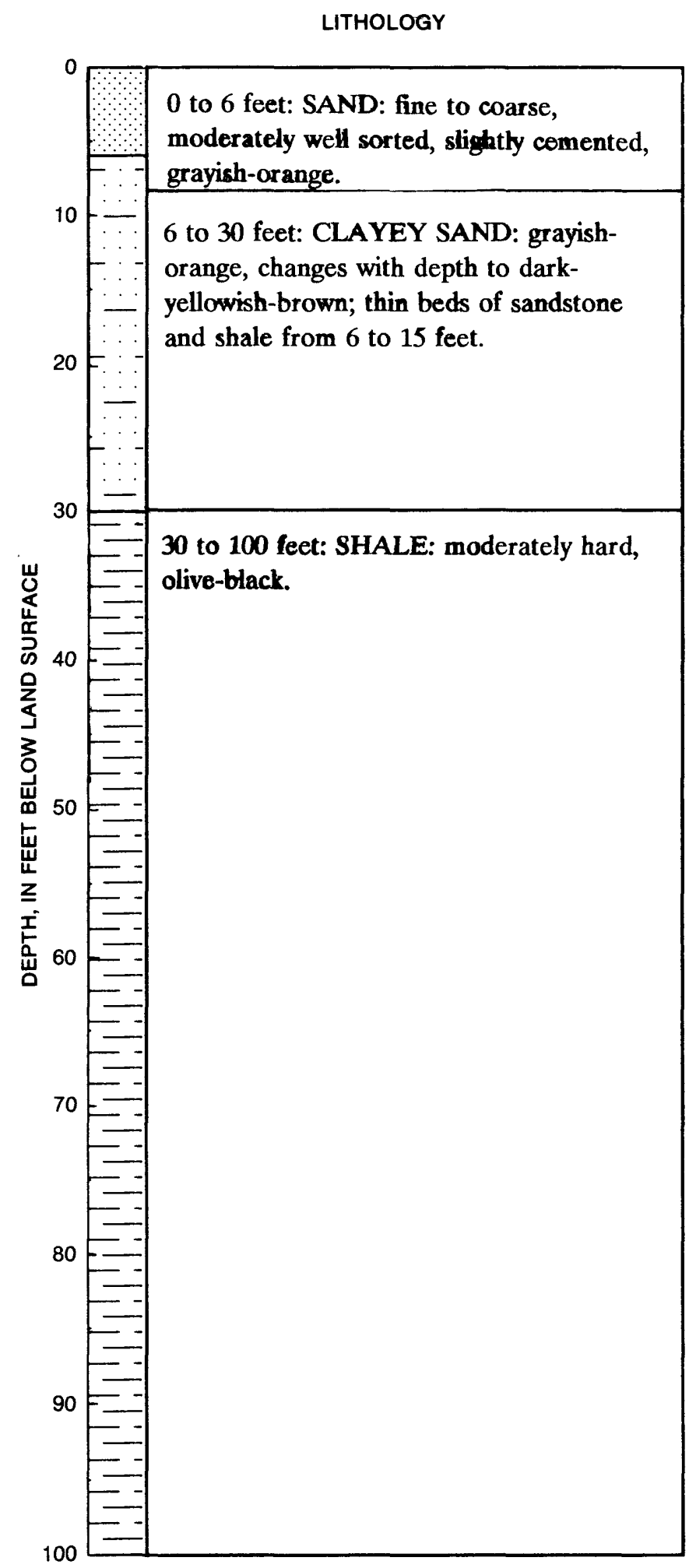

Figure 2. Lithologic log of well 10S/26W-25P1. 

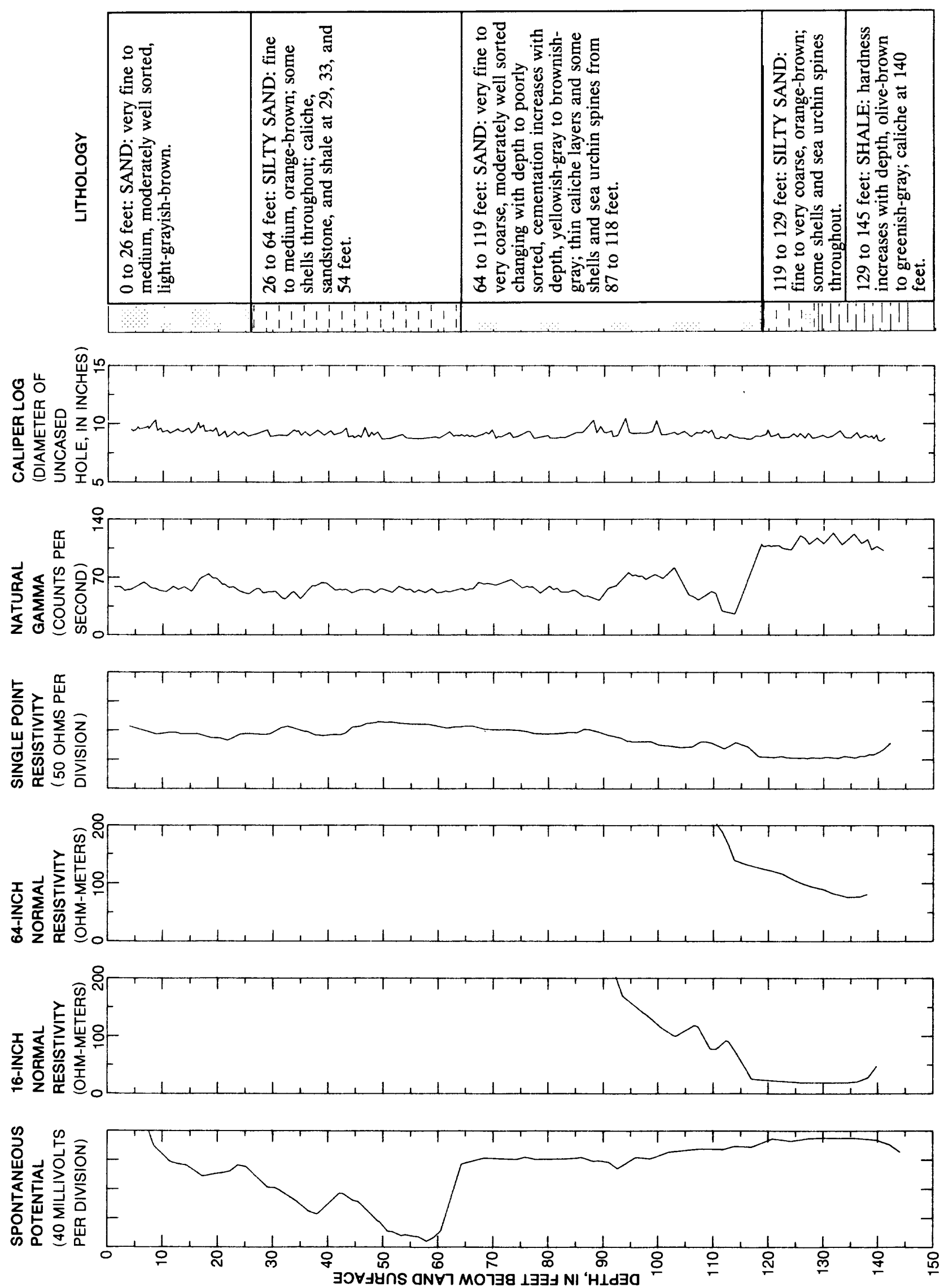

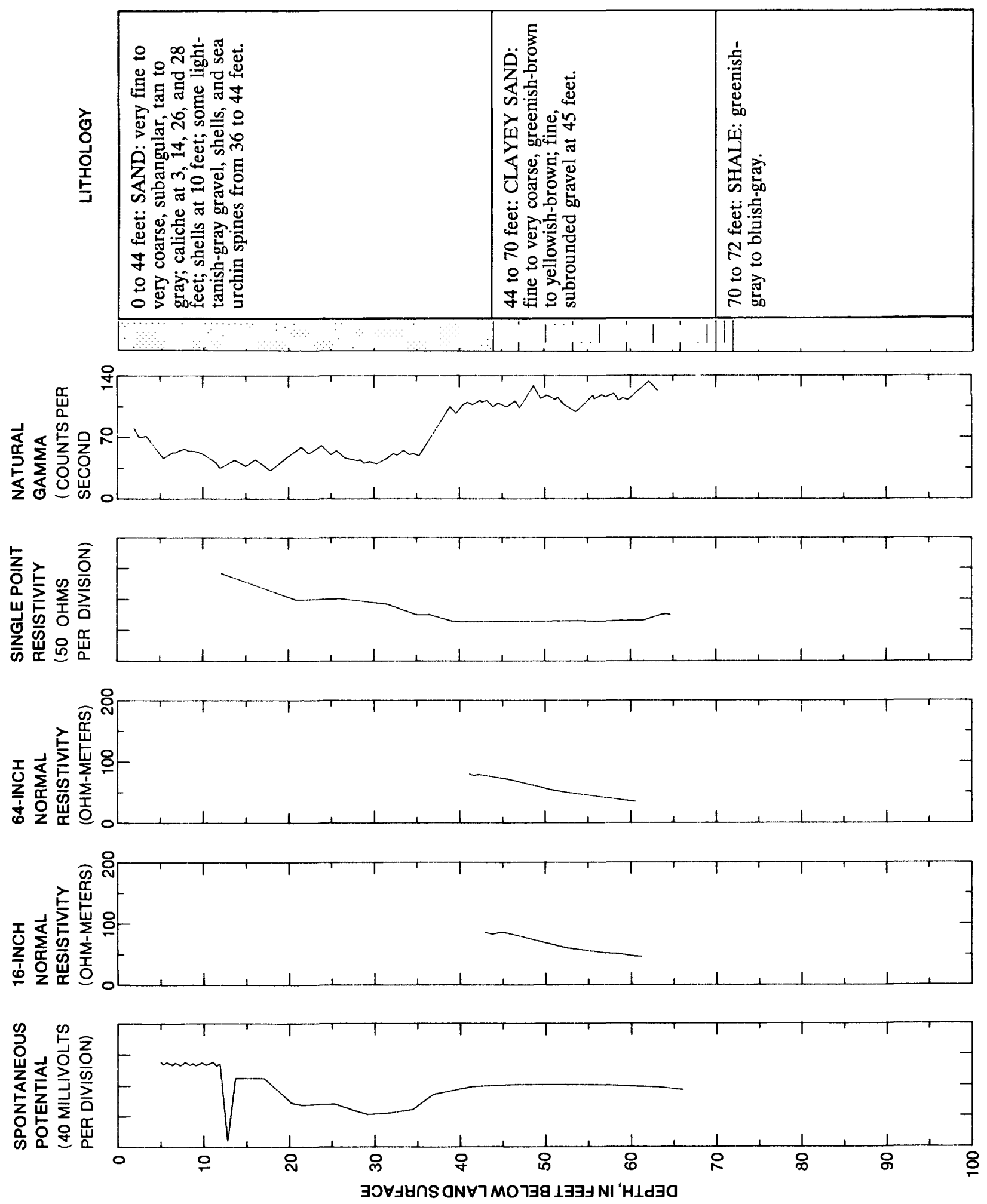

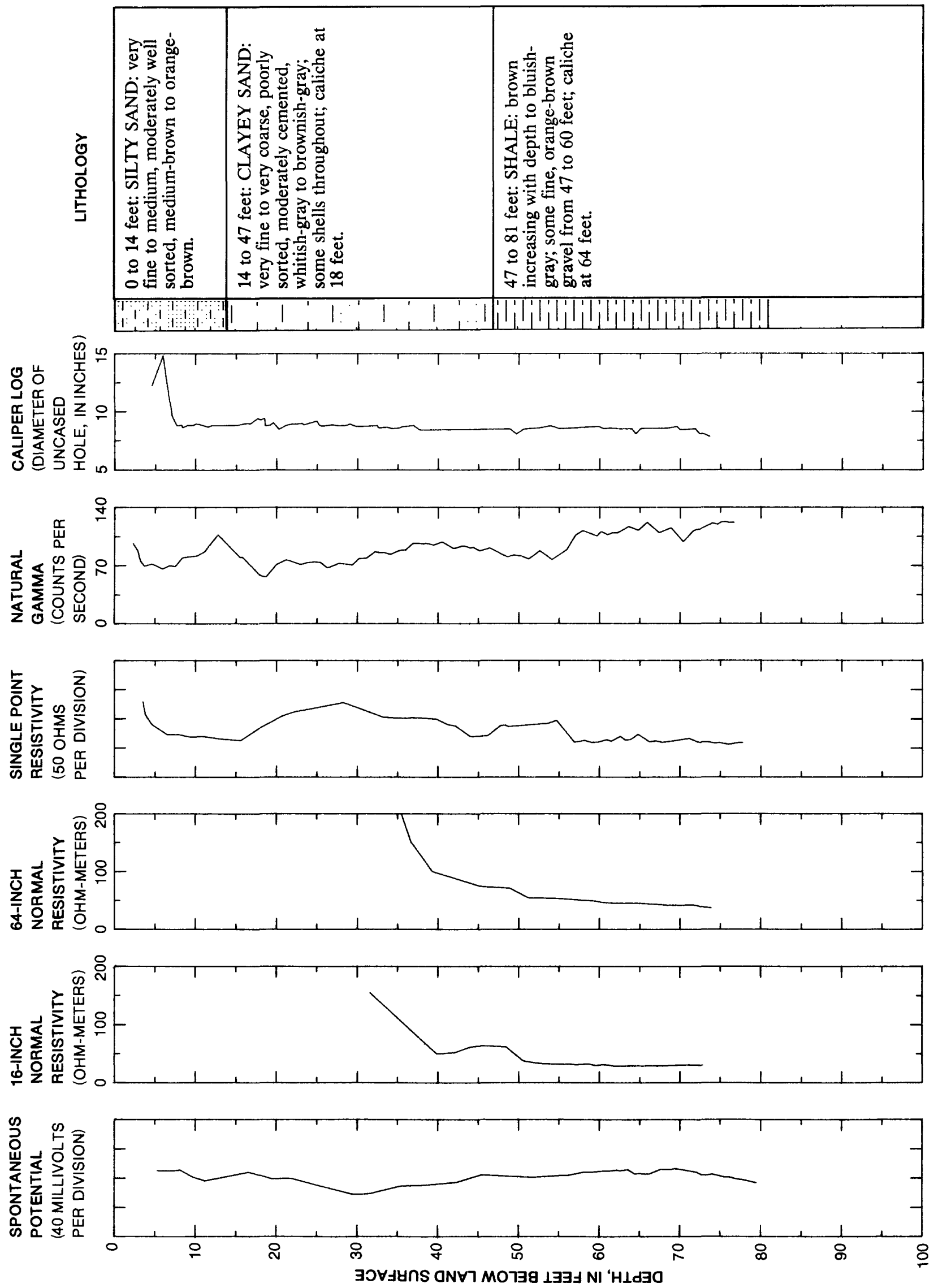

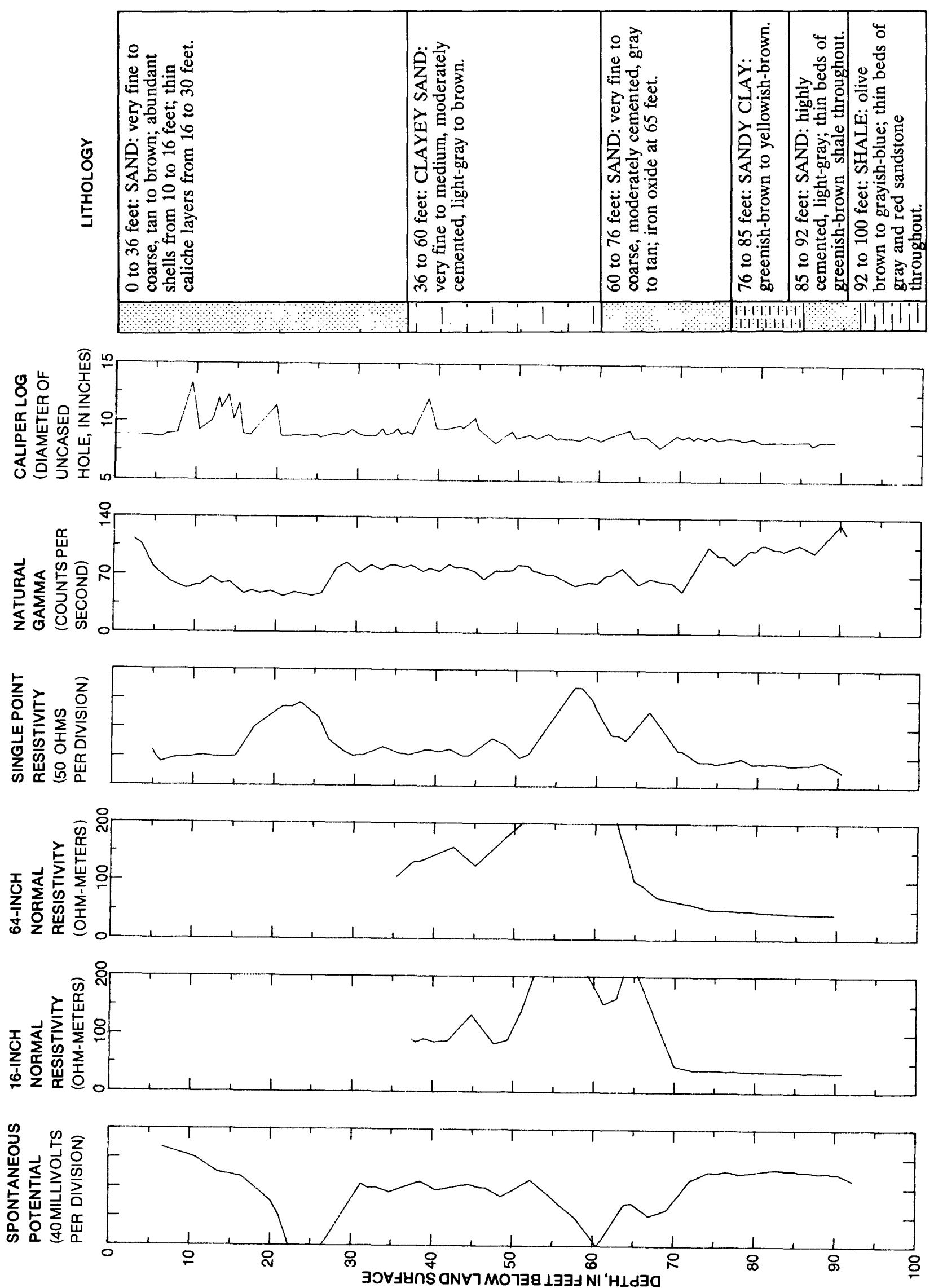

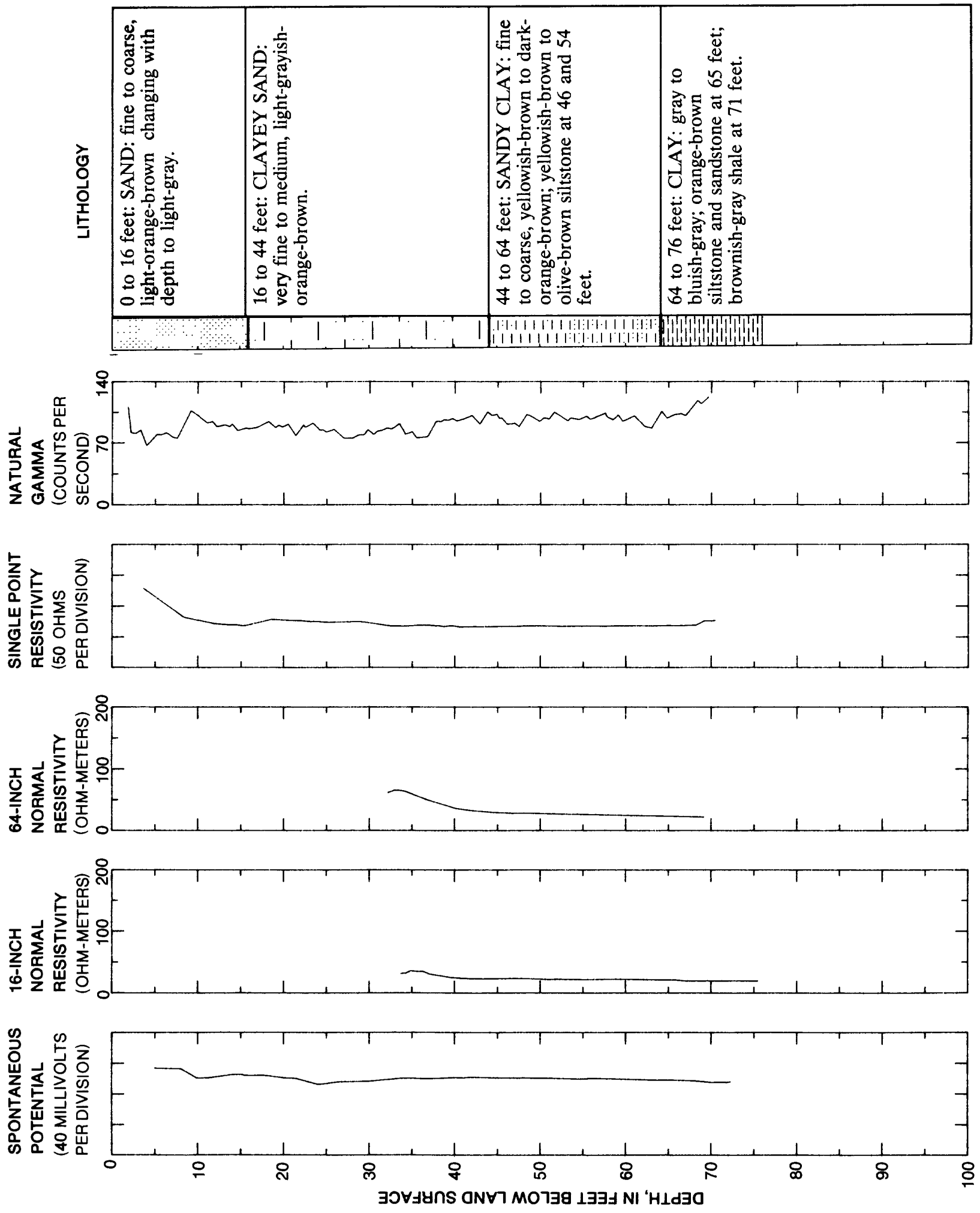

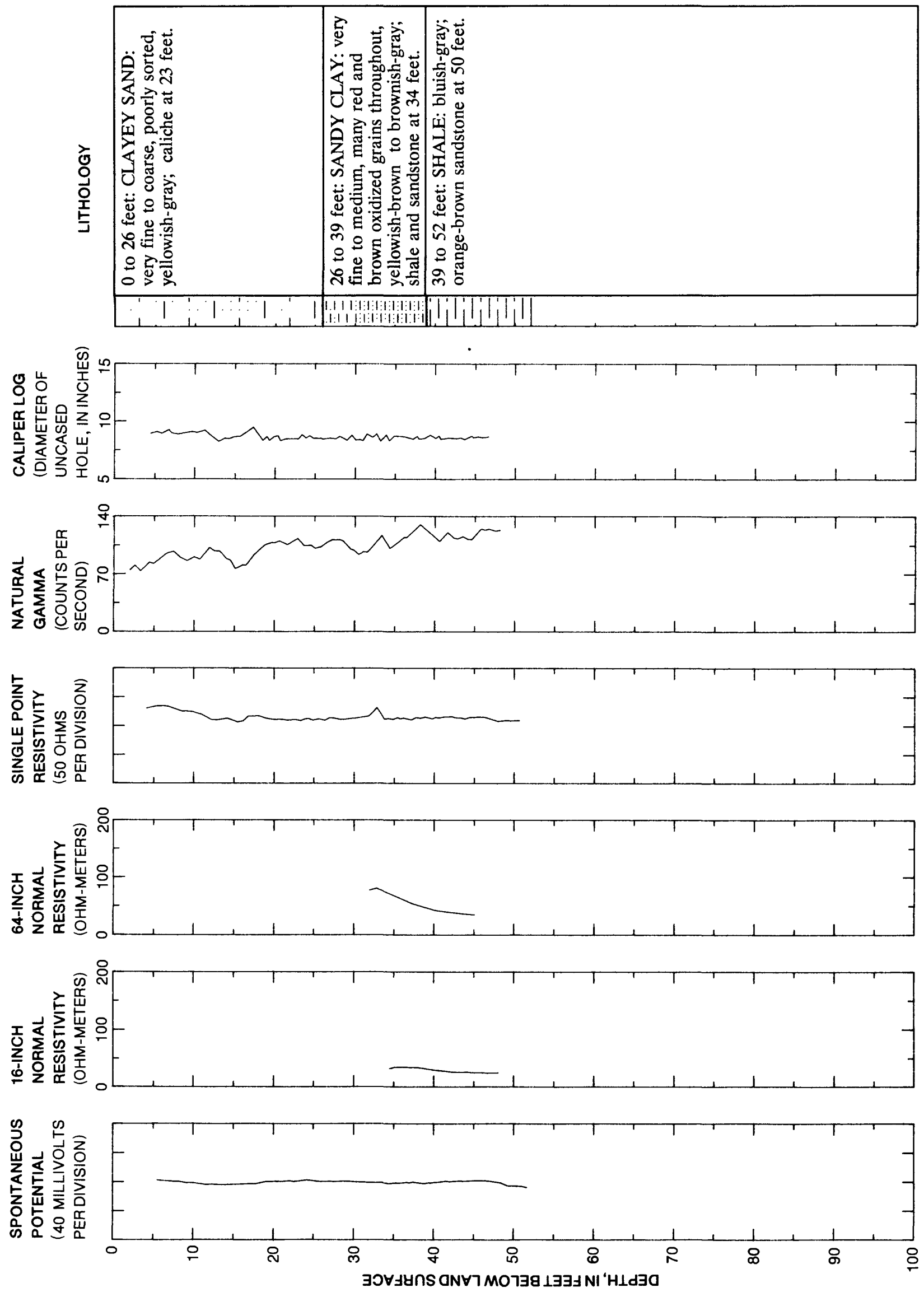

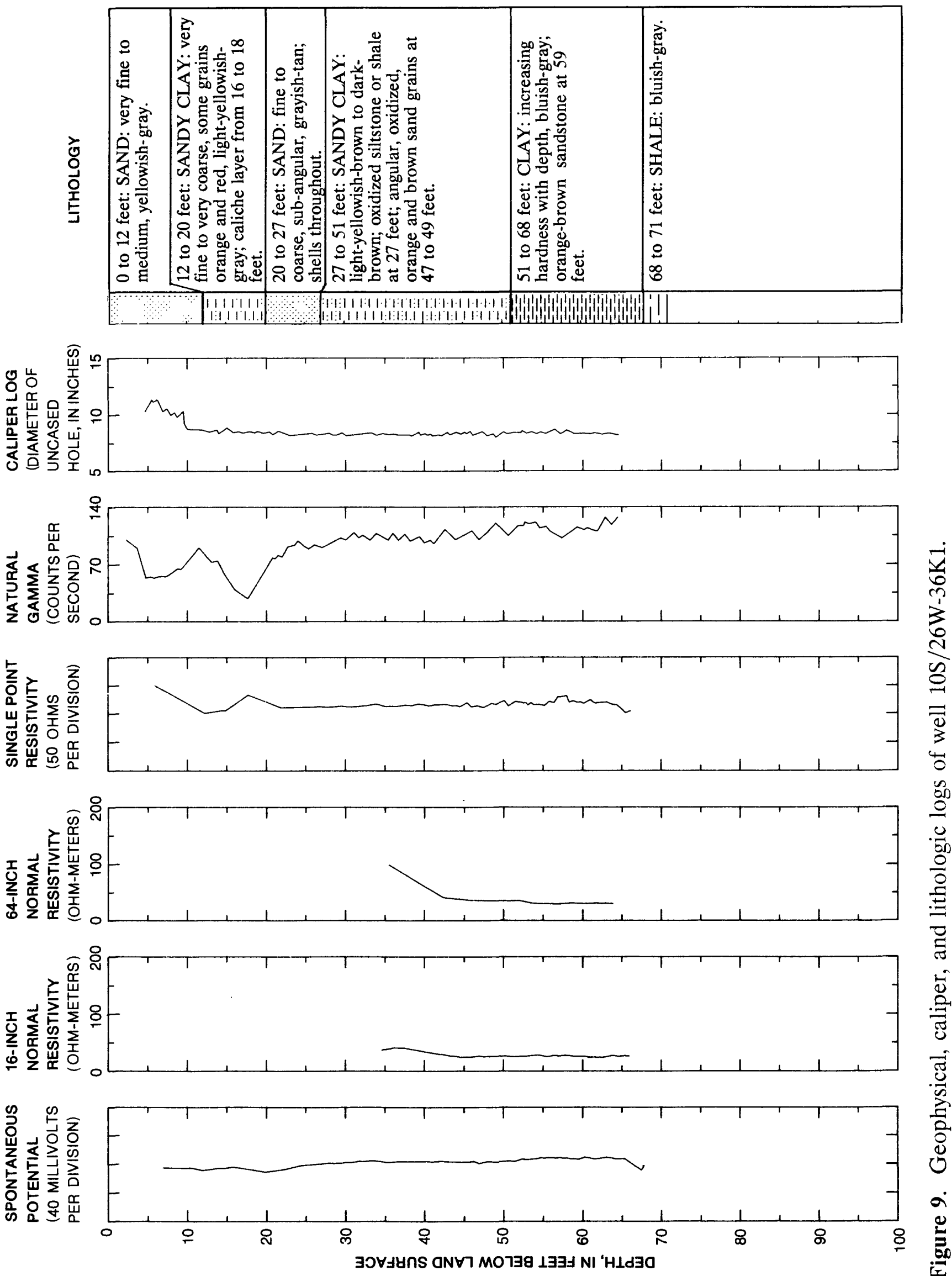

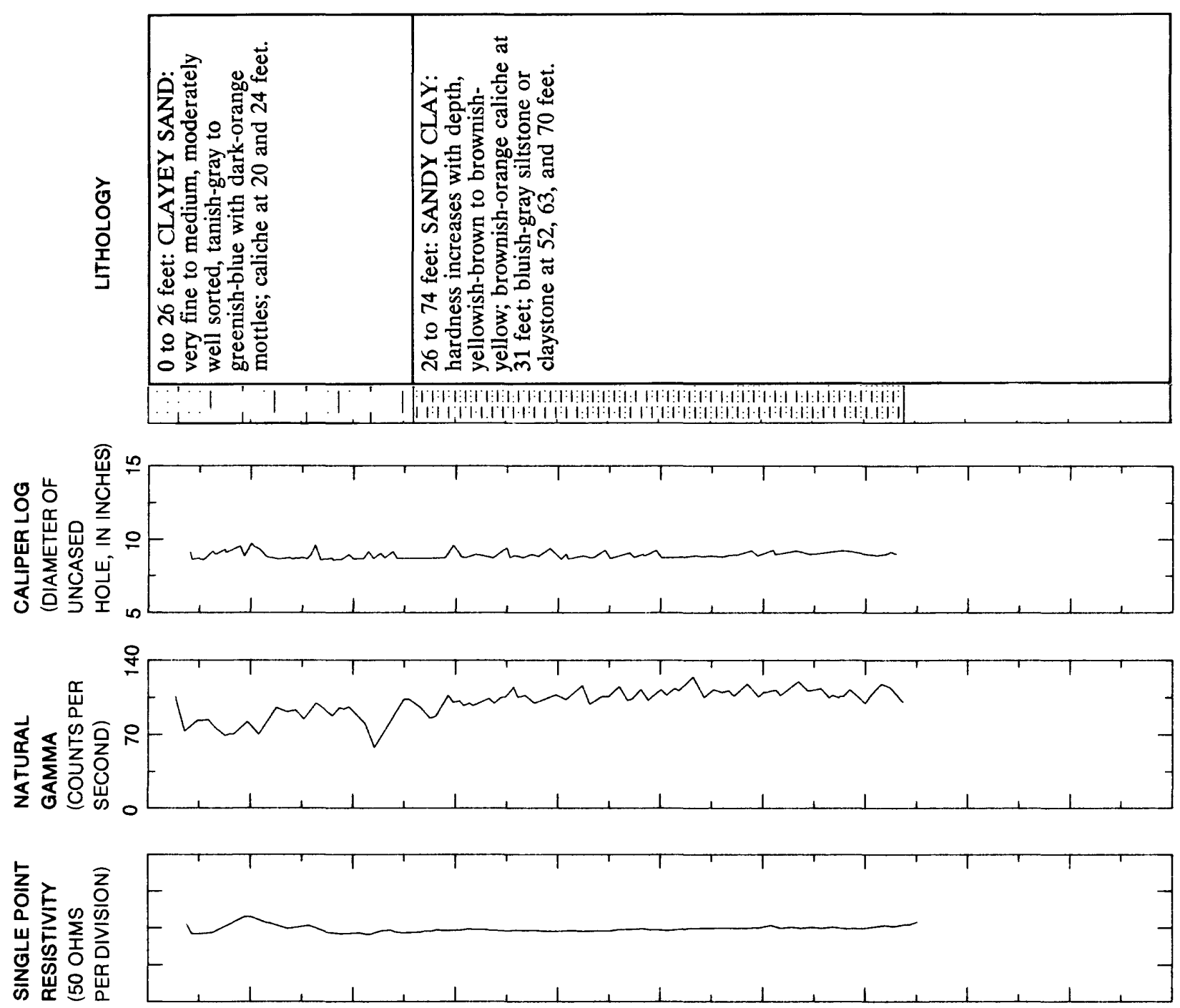

3
0
1
0
0
0
0
0
0
0
3
0
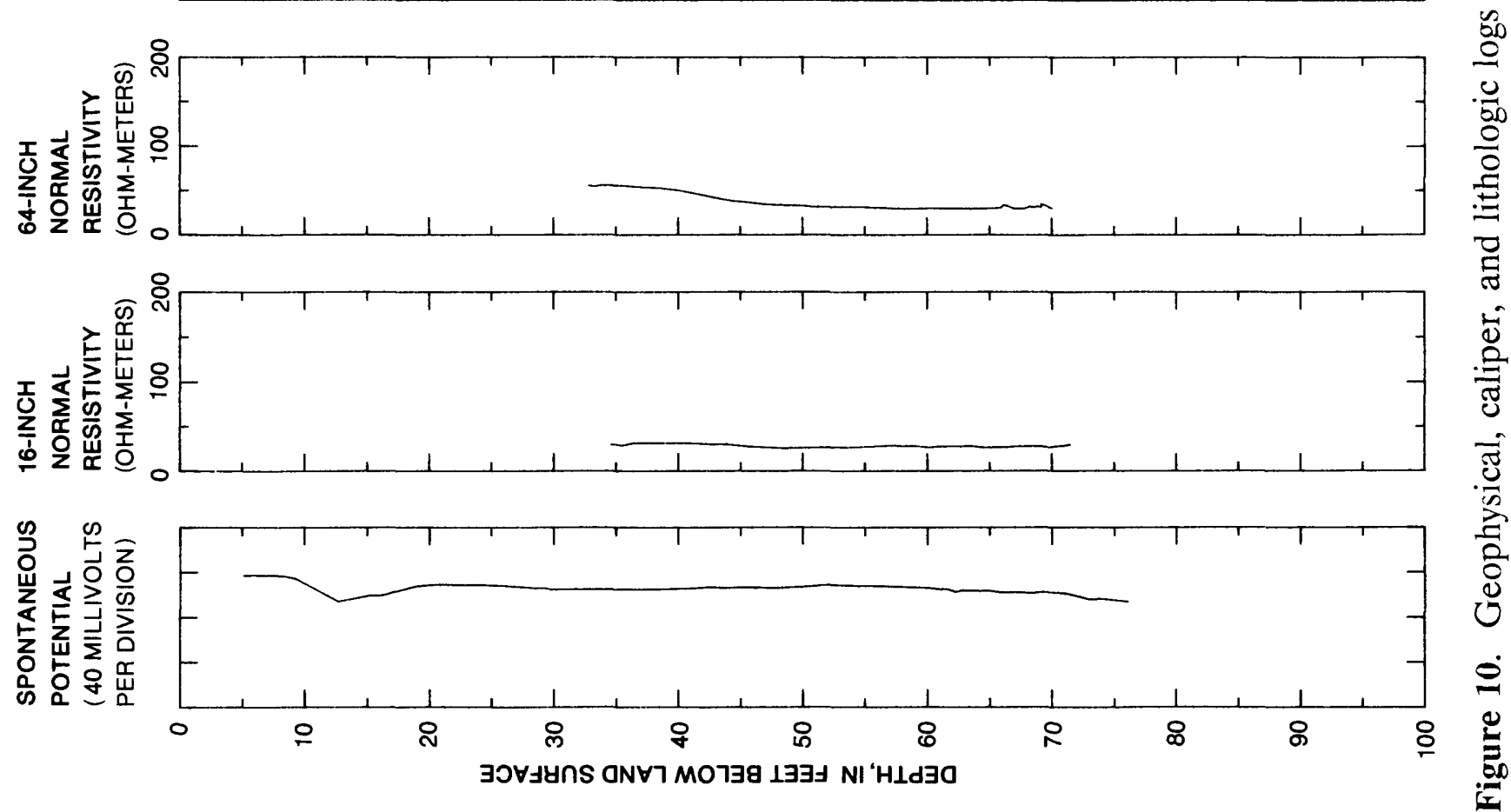

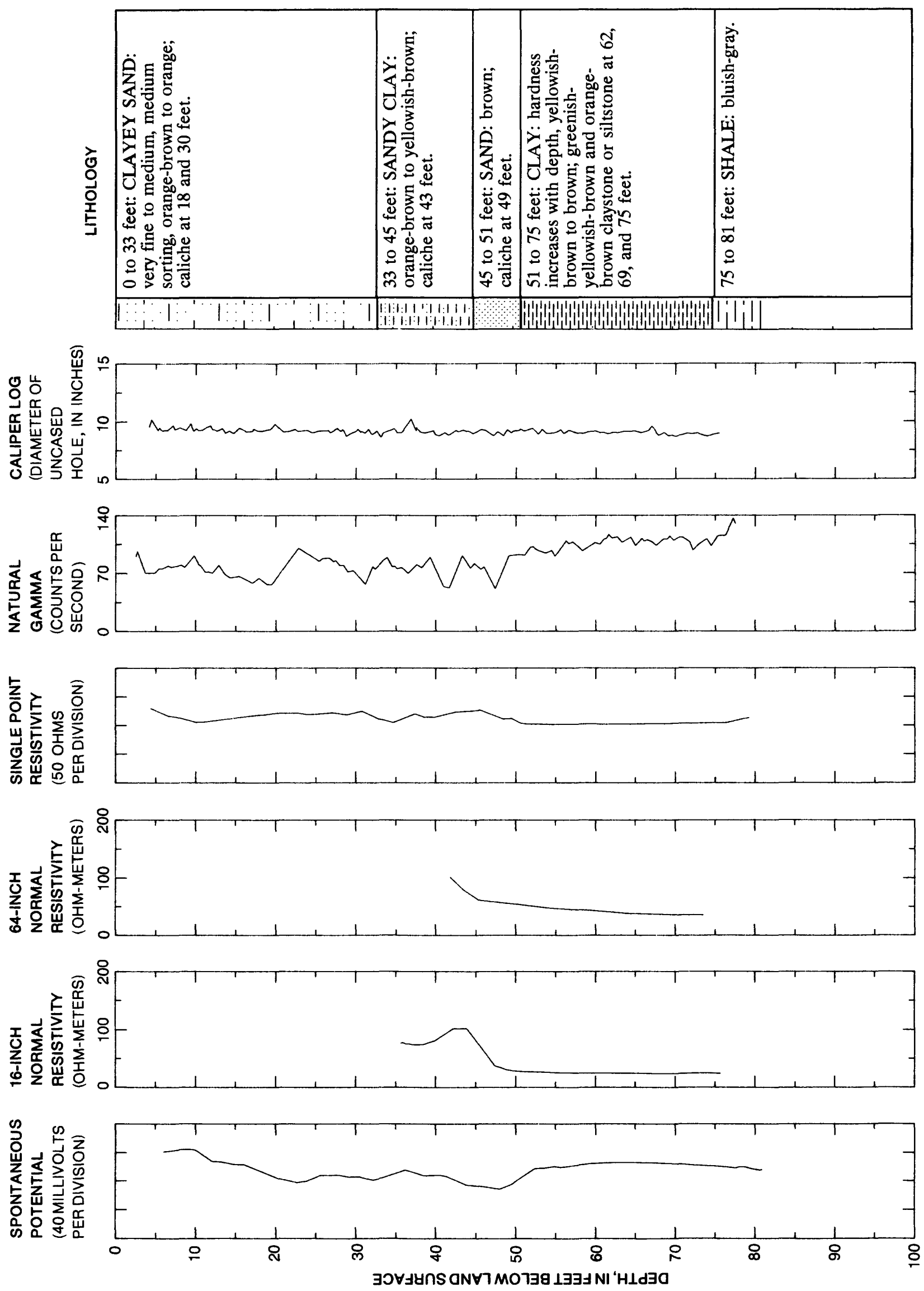

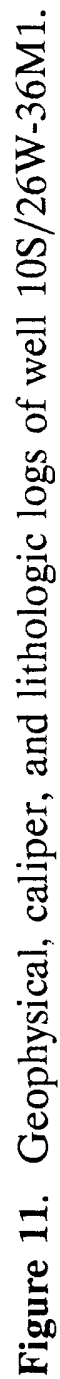


Well 10S/26W-25P1,

May $1-4,1990$

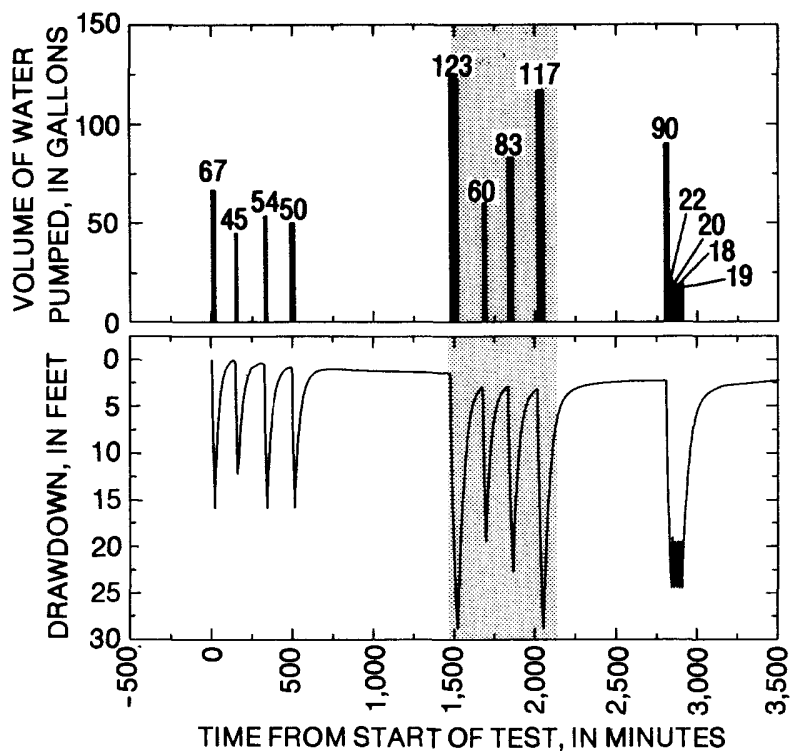

Well 10S/26W-34G1, May 2-4, 1990

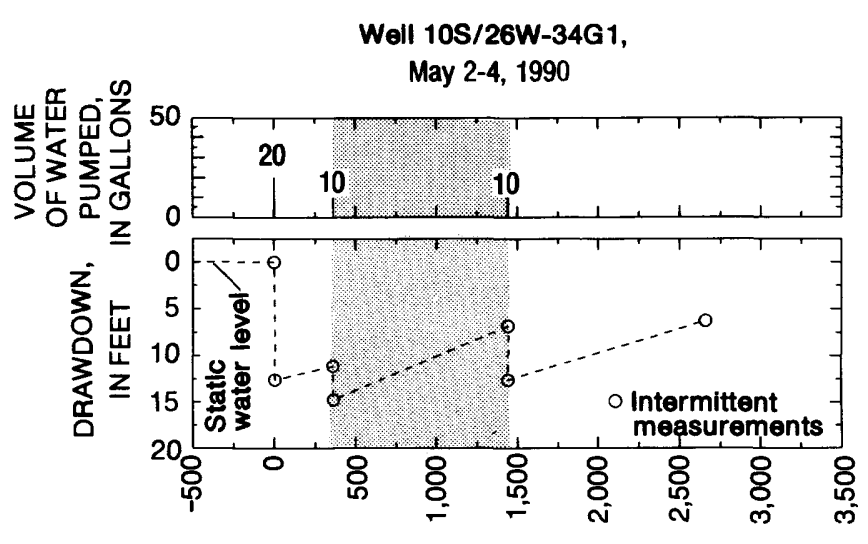

TIMEFROM START OF TEST, IN MINUTES
Well 10S/26W-34L1,

April 24-May 4, 1990

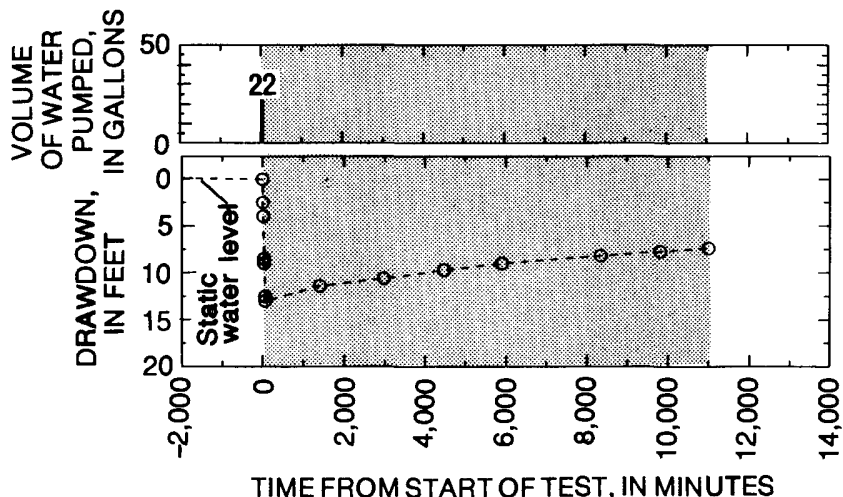

TIMEFROM START OF TEST, IN MINUTES

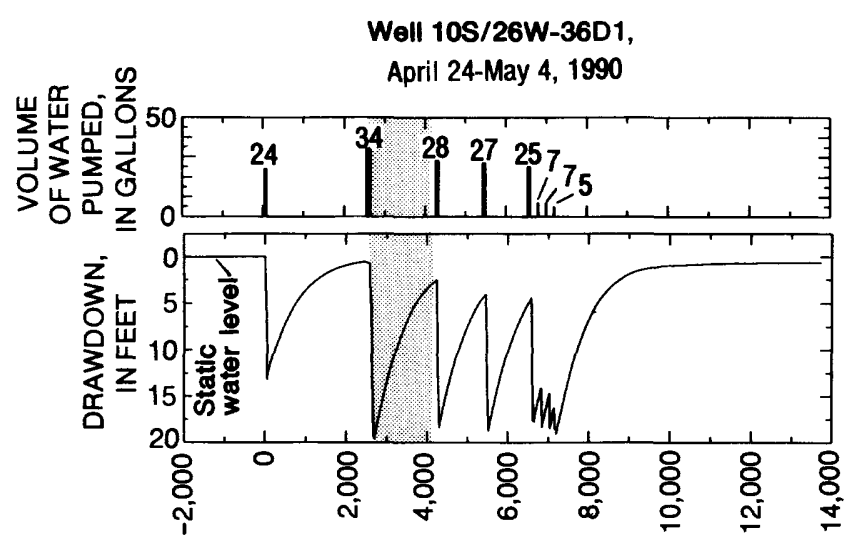

TIME FROM START OF TEST, IN MINUTES

Figure 12. Volume of water pumped and water-level drawdown during testing at selected wells, April and May 1990. Pumping time is indicated by width of bar, and the number at top of bar is gallons pumped. The period of time used to calculate estimated well yield is indicated by shading. 
Well 10S/26W-36E1,

April 24-May 4, 1990
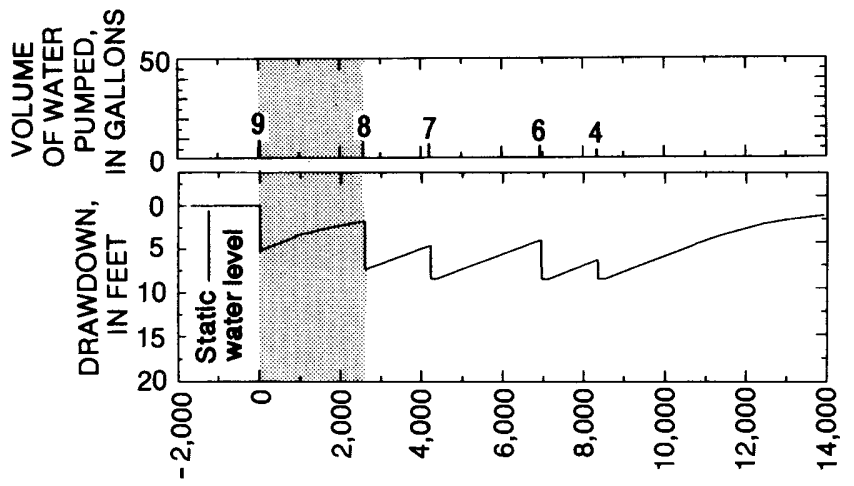

TIME FROM START OF TEST, IN MINUTES
Well 10S/26W-36L1,

September 13-14, 1989

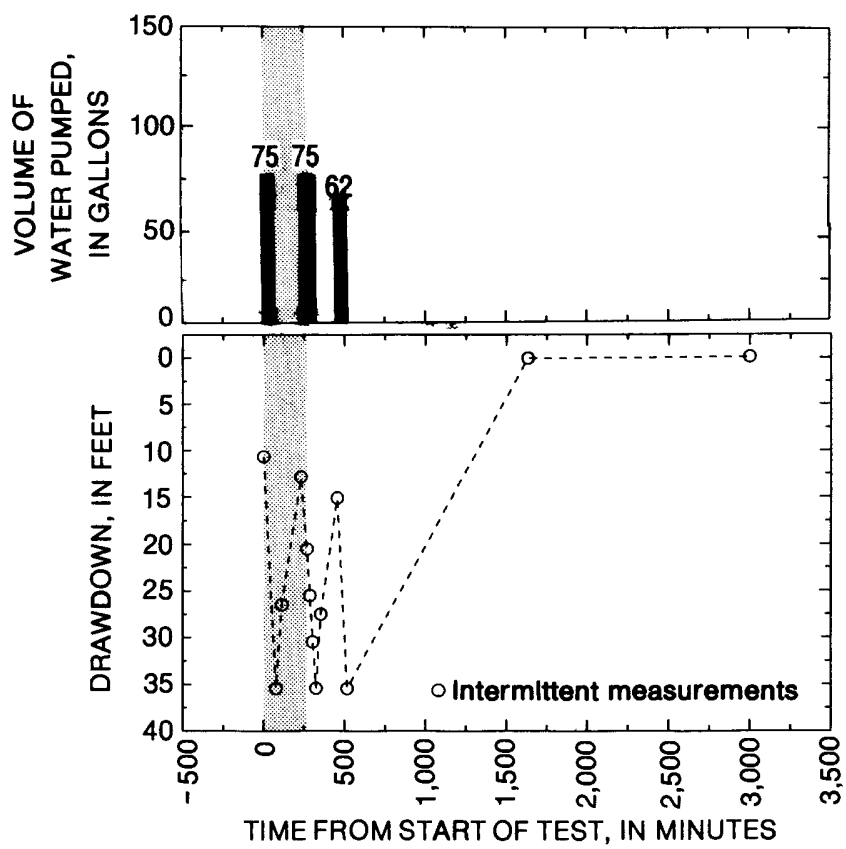

Well 10S/26W-36M1,

April 24-May 4, 1990

April 24-May 4, 1990

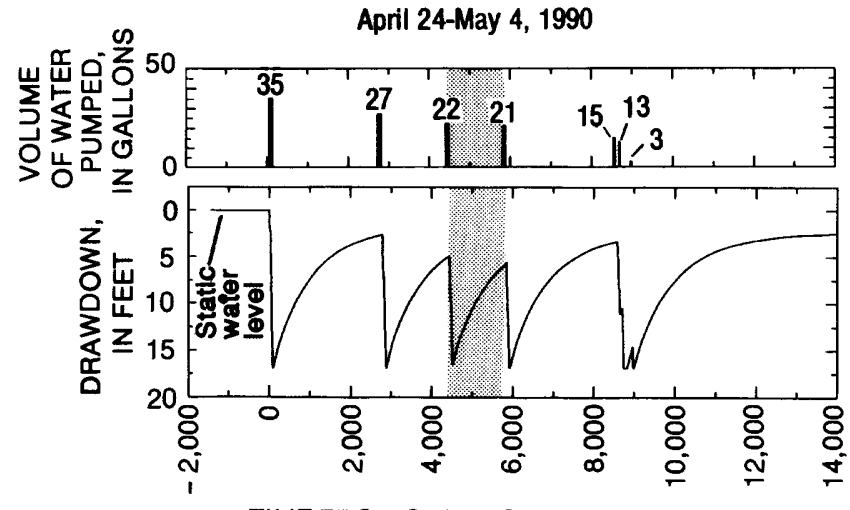

TIME FROM START OF TEST, IN MINUTES
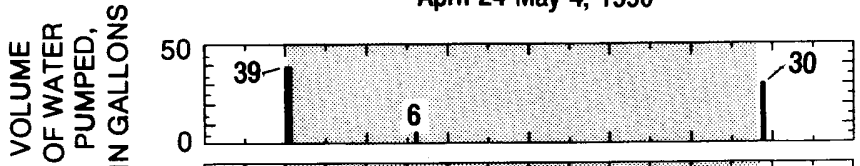

文出

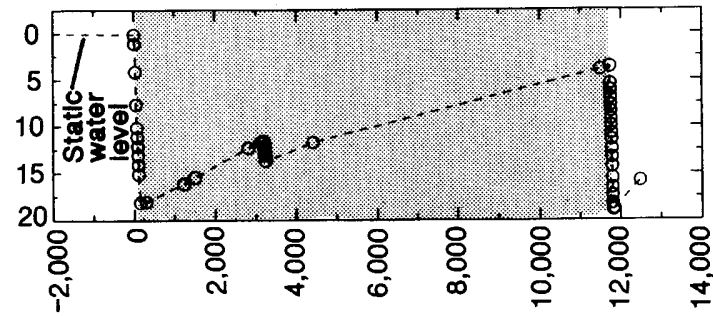

TIME FROM START OF TEST, IN MINUTES

Figure 12.--Continued. 